\title{
ФУНКЦІОНУВАННЯ НЕНОРМАТИВНИХ ФОРМ ПРИКМЕТНИКІВ ІЗ ПРЕФІКСОМ НАЙ-: ВІДОБРАЖЕННЯ АКСІОЛОГІЧНИХ СМИСЛІВ
}

\author{
ДАР'Я РЯЗАНЦЕВА \\ Харківський національний педагогічний університет ім. Г. С. Сковороди, \\ Харків - Україна
FUNKCJONOWANIE NIENORMATYWNYCH FORM PRZYMIOTNIKÓW Z PREFIKSEM NAJ- W JEZZYKU UKRAIŃSKIM: ODZWIERCIEDLENIE ZNACZEŃ AKSJOLOGICZNYCH

\author{
DARIA RIAZANCEWA \\ Charkowski Narodowy Uniwersytet Pedagogiczny imienia Hryhorija Skoworody, \\ Charków — Ukraina
}

STRESZCZENIE. W artykule zaprezentowany został opis teoretyczny funkcjonowania nienormatywnych form przymiotników w języku ukraińskim z prefiksem naj- w różnych rodzajach dyskursu. Analizie poddany został aspekt pragmatyczny powyższych form.

FUNCTIONING OF NON-NORMATIVE FORMS OF ADJECTIVES
WITH THE PREFIX NAI-: REFLECTION OF AXIOLOGICAL SENSES

\section{DARIYA RIAZANTSEVA}

Kharkiv H.S. Skovoroda National Pedagogical University, Kharkiv — Ukraine

ABSRACT. The article deals with the analysis of non-normative adjectives with the prefix nai-. The reflection of axiological senses has been analyzed.

$\Phi$ ункціонально-прагматична спрямованість сучасних лінгвістичних досліджень відкрила можливості для вивчення нових аспектів категорії оцінки, зокрема вивчення функціональної специфіки граматичних одиниць. При цьому важливо враховувати й сферу їх реалізації як засобів вираження оцінки, оскільки в конкретних умовах спілкування первинно неоцінні граматичні одиниці набувають оцінних значень — „саме мовлення вільно інтерпретує реальне й ірреальне, свідоме й підсвідоме, раціональне й ірраціональне, деформує або руйнує природу мовного знака, заново кодуючи світ"1. Лінгвістичні дослідження другої половини XX століття й початку XXI (праці В. Виноградова, Л. Щерби, Р. Якобсона, Н. Арутюнової, О. Вольф, Г. Золотової, О. Бондарка, О. Кубрякової, А. Загнітка, Т. Космеди, О. Ремчукової, О. Халіман та ін.) скеровані на функціональне вивчення категорії оцінки в аспекті тлумачення закономірностей уживання мовних одиниць відповідно до конкретних (оцінних) цілей мовця, що характеризує оцінку як категорію прагматичну, дискурсивно зорієнтовану, а оцінні засоби - як носії прагматичного значення в комунікативному процесі.

${ }^{1}$ Т. Космеда, Аксіологічні аспекти прагмалінгвістики: формування і розвиток категорії оцінки, Львів 2000. 
Цікавою, але майже не вивченою проблемою в прагмалінгвістичному аспекті є природа оцінки, що виражається словами різних частин мови, а також функції граматичних одиниць як засобів вираження оцінних значень 3 урахуванням їх прагматичних характеристик, що й зумовлює актуальність досліджень у цьому ракурсі.

Мета наукової розвідки — описати функціонування ненормативних форм прикметників із префіксом най-, проаналізувати особливості їх прагматичних значень.

Граматичне значення завжди супроводжує лексичне, тому в процесі утворення ненормативних форм прикметників на основі невідповідності їх уживання нормам української мови, використанні нетипових словотвірних моделей породжуються оцінка й додаткова експресія, адже, висловлюючи свою думку або розповідаючи про відповідні події і под., людина не може абсолютно абстрагуватися від свого ставлення до висловлюваного й так чи так виражає свою оцінку, а закріплюючи за певним явищем слово, людина не тільки називає це явище, предмет, але в самому слові вже виражає й своє ставлення до нього: „Слова перебувають у безперервному зв’язку з усім нашим інтелектуальним та емоційним життям (...). Слово є одночасно і знаком думки мовця, й ознакою всіх інших психічних переживань, що входять у завдання й наміри повідомлення"2.

Розглянемо детальніше функціонування в різних видах дискурсу ад'єктивних лексем із семантикою надмірної кількості / інтенсивності ознаки, що вносить у структуру значення префікс най- і може супроводжуватися актуалізацією саме цієї семи / грамеми. Формантом, що передає значення високого ступеня вияву ознаки, вказує на більшу проти звичайної міру якості, $\epsilon$ продуктивний префікс най-. Власне прикметниковий префікс-модифікатор най- - носій граматичного значення високого ступеня вияву кількісної ознаки.

Останнім часом в українській мові спостерігаємо порушення граматичної норми: утворення форми суперлатива та елатива із пропуском так званої „середньої ланки” - форми компаратива, тобто перехід від звичайної форми прикметника одразу до найвищого ступеня, порівн.: важливий - найважливий, мізерний - наймізерний. За граматичною нормою повинно бути важливий - важливіший - найважливіший (якнайважливіший, щонайважливіший); мізерний - мізерніший - наймізерніший. До сьогодні такі форми не привертали уваги дослідників, хоча не можна твердити, що вони не були відомі раніше, порівн.: Невже по тисячі зусиль Це буде крапля найостання? (Б. Тен „Мов блудний син на чужині”, 1934 р.). На сучасному етапі розвитку української мови уживання прикметників (іноді прислівників) типу найславний, найвеликий, найдивовижний, найскладний, найнезахищений набуло ознак стихійного явища, що дає змогу розмірковувати про певну тенденцію, а саме - тенденцію до спрощення мови: префікс най- вже вказує на вищий ступінь ознаки, зміст якого потрібно донести до співрозмовника, тому третя, проміжна форма або суфікси -іш-, -ш-, що повинні додаватися до форми суперлатива та елатива, стають зайвими. Порушенням норми є також додавання префікса най- до відносних прикметників, позбавлених, згідно із граматичними нормами, здатності ступенюватися та виражати різний ступінь вияву ознаки, порівн.: Це було найвидовищне шоу (радіо „Ера”, 18.07.2011 р., 14:15); Животійте, братове, розкошуйте, сестри, у найвисокій жазі та млості. Най вас проведе прощальним жес-

\footnotetext{
${ }^{2}$ В. В. Виноградов, Исследования по русской грамматике, Москва 1975.
} 
том Господь... і майте, щзо маєте (“Вечірній Київ”, 9.04.1999, с. 6); Зволікання з виконанням директиви щзодо Курляндського угрупування загрожувало найнепередбачуваними наслідками для командування 2-м Прибалтійським фронтом (“Вечірній Київ”, 6.05.2000, с. 4); „Податки та бухгалтерський облік”- найбухгалтерська газета (з телереклами).

Утворення вищого ступеня порівняння із пропуском „середньої ланки” ступенювання деякі мовознавці, зокрема К. Ленець, пов'язують із наявністю в українській мові суплетивних форм типу кращий - найкращиий (до гарний), гірший - найгірший (до поганий), у парадигмі ступенювання яких відсутня звичайна форма спільнокореневого прикметника ${ }^{3}$, за аналогією до таких форм мовці додають префікс най- до інших прикметників. Ступенювання прикметників, що відбувається із випадінням суфікса -іш- у середині слова, описує В. Максимчук, подаючи такий приклад, порівн.: Я мозок...Я очі ... Я руки... Я вчора щзе бачив і мислив, найтонші відточував звуки, і найвідтоншений вислів (О. Богачук, „Я мозок”) ${ }^{4}$. На думку дослідника, такі авторські лексичні новотвори $є$ свідомим порушенням норми, адже „вони надають інновації експресивності, увиразнюють смислове наповнення контексту, естетизують висловлювання"5.

Частково особливості функціонування прикметників із суфіксом най- та його повторами простежила Л. Семененко. Дослідниця називає таке відхилення від літературної норми „нагромадженням афіксів-модифікаторів” і твердить, що воно слугує створенню „граничного експресивного напруження” в тексті, порівн.: За оградою витихло місто, / Загриміли пісні солов'я.../ Цілував твої руки, пречиста, / Найпречистіша жінко моя (М. Сич, „Давня молитва”) ${ }^{6}$. Форму вищого ступеня порівняння прикметника найпречистіша утворено, вочевидь, за такою схемою: пречистий — пречистіший — найпречистіший, що $€$ також порушенням правил ступенювання прикметників (прикметник пречистий не може ступенюватися, оскільки належить до морфолого-словотвірної категорії надмірної інтенсивності ознаки). Отже, оказіональна контамінація формантів семантико-граматичної категорії співвідносної міри якості та категорії безвідносної міри якості, накладання синтетичного й аналітичного засобів вираження становить художній прийом, що грунтується на використанні значеннєвого потенціалу граматичних форм, актуалізації певних грамем.

Ще одним художнім прийомом, унаслідок використання якого утворюються ненормативні метафоризовані форми ступенів порівняння прикметників, є градаційне збільшення експонентів у поетичному тексті, порівн.: Погрівся. Тоді пригнув лапою собі до носа коров'як, нюхнув його верхню квітку, під нею понюхав нижчу, під нижчою ще нижчу, під нижчою щзе нижчішу, під тією найнижчішу, а попід найнижчішою най-найнайнижчішу, вже при самій землі на піску (М. Вінграновський, „На добраніч”)7. Подвоєння префікса найпростежуємо в нормативно утворених словоформах суперлатива / елатива від якісних прикметників, порівн.: Не бійтесь...Так...Тепер в иче скло дивіться /

${ }^{3}$ К. Ленець, Помилка чи закономірність, [в:] Електронний ресурс: http://kultura movy.org. ua/KM/pdfs/Magazine60-12.pdf.

${ }^{4}$ O. Богачук, Поезіï, [в:] Електронний ресурс: http://poetry.uazone.net/bogachuk/.

${ }_{5}^{5}$ В. Макси мч ук, Естетика авторського новотвору як результат порушення мовних норм, [в:] „Наукові записки”, Острог 2012, вип. 22, с. 63-72.

6 Л. А. Семененко, Аксіологічно значущі відхилення у функціонуванні форм компаратива / суперлатива в украӥнському поетичному мовленні, [в:] „Культура народов Причерноморья”, Сімферополь 2008, вип. 142, с. 250-253.

${ }^{7}$ М. Вінграновський, На добраніч, [в:] Електронний pecypc: http://ukrclassic.com.ua/ katalog/v/vingranovskij-mikola/105-mikola-vingranovskij-na-dobranich. 
I думайте про найнайголовніше / Iз того, щзо намислили чинити / найближчим часом (Н. Тихий, „Рraemonitor”)"; Складали ми етюди. В коридорах було чути: „Най-най-най-найважсливіший екзамен” (М. Вінграновський, „Рік 3 Довженком”)9. Різноманітні форми повторення префікса най- — це „намагання посилити виразовість третього ступеня" 10 , гіперболізувати ознаку, виражену прикметником звичайного ступеня. Об'єкт ступенювання взагалі може бути опущений, порівн.: Директор кінотеатру пригостив нас карамелями, побажав нам всіляких-всяких-що-не-най-най-най-най... (М. Вінграновський, „У глибині дощів") ${ }^{11}$; Ступив $і$ я у води проминання / свого най-най...і поривання / останні сплески - тільки рудименти / тї̈ пори, коли ходила боса / душа по склу й не помічала скла (В. Базилевський, „Моя душа ходила боса...”) ${ }^{12}$; Давно уже сонечко сіло за гай, $і$ зорі сказали: лягай, засинай. I мама говорить: Ти в мене най-най..., лягай, моя рідна, скоріш засинай (О. Морозенко, „На добраніч”)"13; Є... поблюзуємо та проведемо тінню, щуоб майже-майже луснуло струною... Найтонша найпромовніша най- най... Але який цирульник із музики! Хай рветься. (Г. Осадко, „Портрет-пейзаж-портрет”) $)^{14}$. Формально вираженим у наведених поезіях $є$ тільки експлікатор найвищого ступеня порівняння най-, що дублюється кілька разів, передаючи найвищий ступінь інтенсивності ознаки, і графічно (крапками) позначене місце розміщення цієї ознаки.

Яскравою ілюстрацією аналізованого явища є діалог Д. Павличка з I. Драчем, де смисл, репрезентований формою найвищого ступеня порівняння, посилюється кількаразовим повторенням частини слова, порівн.: Іване, а скажи мені, як у вас кажуть, коли пень величезний та щуе й з корчаками, як його обзивають? Ну, корчакуватий пень! - А коли серед усіх корчакуватих пнів с найбільш корчакуватий, як на нього кажуть? - Ну, найкорчакуватіший! - Ну, а як серед усіх найкорчакуватіших є дуже вже страшний, до жаху корчакуватий? - Що ти до мене причепився? У нас таких не буває - це у вас такі... - У нас на такого кажуть найкорчакувакуватіший... (І. Драч, „Найкорчакувакуватіший”) $)^{15}$. Очевидно, такі утворення мотивовані необхідністю вербалізації аксіологічних значень, актуалізацією відповідної прагматики.

Лексеми, утворені із багаторазовим повторенням префікса найнай-, є характерними для сучасного мовлення українців, що доводять численні приклади 3 художніх, публіцистичних джерел, інтернет-комунікації, порівн.: Після изього ми повернулися до району Дубаїв, де розташовано більшість хмарочосів, проїхали по одній з иентральних магістралей міста - вулииі Шейха Заєда (президента та головного натхненника і засновника Об 'єднаних Арабських Еміратів), і нарешті дісталися най-най-найвищого будинку в усьому світі, яка при-

8 Л. А. Семененко, Зазнач. джерело, с. 250-253.

${ }^{9}$ М. Вінграновський, В глибині дощів. Повісті, оповідання, Київ 1985.

${ }^{10}$ Ю. О. Карпенко, Ступені порівняння різних частин мови та їхні функиії, [в:] „Мовознавство", Київ 2010, № 2/3, с. 41-48.

${ }^{11}$ М. Вінграновський, В глибині дощів. Повісті, оповідання, Київ 1985.

${ }^{12}$ В. Базилевський, Моя душа ходила боса..., [в:] Електронний pecypc: http://virchi.narod. $\mathrm{ru} /$ poeziya/bazilevskiy.htm.

${ }_{13}$ O. Морозенко, На добраніч, [в:] Електронний ресурс: http://www.library.kherson.ua/ young/kolosok/TKI.htm.

${ }^{14}$ Г. Осадко, Портрет-пейзаж-портрет, [в:] Електронний ресурс: http://maysterni.com/ user.php?id $=2439 \& \mathrm{t}=4 \&$ type $=1 \& \mathrm{p}=1$. c. 2 .

${ }^{15}$ I. Драч, Найкорчакувакуватіший (образок), [в:] „Літературна Україна”, Київ 2009, вип. 32, 
кувала до себе погляди ледь не всіх пасажирів нашого літака, щзе коли ми тільки підлітали до Дубаӥв — Бурдж Халіфа ${ }^{16}$; Най-най-зимовий табір „, Per aspera ad astra" "17; Найвідоміший кіоск з начіональною най-най-берлінською їжею Curry Wurst (сосиска з прянощзами) і ї̈ похідними та родичами ${ }^{18}$; Не позичаймо розуму в чужсиниів з най-най-найвідоміших й найавторитетніших ${ }^{19}$; Йому, як най-найсвятішому, ночами почала з'являтися Діва Марія ${ }^{20}$.

Характерною тенденцією сучасної мови є також використання префікса найу рекламних текстах, зокрема назвах магазинів, торгівельних центрів, рекламних оголошеннях, порівн.: Найсмачніші десерти та найсвіжніша випічка ${ }^{21}$; Найсвіюіша курятина ${ }^{22}$; „Найсмачніша” косметика для тіла ${ }^{23}$; Найдешевше таксі ${ }^{24}$; Наймодніші головні убори ${ }^{25}$.

Використання елатива в рекламних текстах $є$ характерним саме для сучасної доби, i, на думку дослідників рекламних текстів (Ю. Булика, В. Зірки, Л. Амірі), використовується через відсутність реальних відмітних характеристик товару, що могли б вигідно виділити його серед товарів-конкурентів. Рекламісти змушені використовувати особливі мовні прийоми, що дають змогу актуалізувати у свідомості адресата такий клас порівняння й такі параметри порівняння, на тлі яких рекламована марка виглядає найбільш виграшно, привернути увагу покупців своїми вираженими позитивними ознаками. Отже, для створення відповідного ефекту автори рекламних текстів залучають численні особливості мовних одиниць, зокрема й оцінний потенціал прикметників та їх граматичних категорій.

Ненормативні форми ступенів порівняння із багаторазовим дублюванням префікса най- активно репрезентовані також у сучасних текстах поздоровлень, привітань, порівн.: Вітаю, ти найнайнайкраща! ${ }^{26}$; Вітаємо Максимка з рочком! Бажаємо всього найнайнайкращого! ${ }^{27}$. Вочевидь, мовці використовують такі повтори для утворення лексем, що містять максимальну позитивну оцінку, оскільки тексти поздоровлень завжди відрізняються піднесеною позитивною тональністю.

Серед інших ступеньованих прикметникових форм із префіксом най- привертає увагу лексема найперший, яку Академічний тлумачний словник української мови подає як нормативну форму найвищого ступеня порівняння до першийㄹ․ На думку Т. Космеди, дана лексема „в процесі функціонування в текстах (дискурсах) може набувати різної семантики, репрезентувати низку прагматичних смислів"29. Дослідниця аналізує позитивно оцінні ступеньовані фор-

${ }^{16}$ Електронний ресурс : http://reporter.korrespondent.net/traveler/6728/6787.

${ }^{17}$ Електронний ресурс : http://www.cym.org/ua/news/intervju_Viktoria-Koljada.asp

${ }^{18}$ Електронний ресурс : http://nonametraveller.wordpress.com/

19 „Літературна Україна”, 07.04.2005, с. 13

20 „Літературна Україна”, 2005, 07.04.2005, с. 21

${ }^{21}$ Електронний ресурс : http://vipon.com.ua/lviv/78454.html

${ }^{22}$ Електронний ресурс : http://www.ryaba.com.ua/video/dSZ7ApVARWk

${ }^{23}$ Електронний ресурс : http://lady.tochka.net/ua/21798-vybor-lady-samaya-vkusnaya-kosmetikadlya-tela/

${ }^{24}$ Електронний ресурс : http://board.lutsk.ua/topic/123018-naideshevshe-taks/

${ }^{25}$ Електронний ресурс : http://lady.ua/ukr/moda/odezhda/2010.11.22.samue-modnue-golovnueuboru-zimu.2010-2011

${ }^{26}$ Електронний ресурс : http://rock.lviv.ua/article/15341/

${ }^{27}$ Електронний ресурс : http://www.malecha.org.ua/forum/index.php?showtopic=11505

${ }^{28}$ Словник украӥнської мови, в 11 тт., Київ 1980, т. 11, с. 187.

29 Т. А. Космеда, Пам'ять мовної особистості і феномен прецедентності: потениії дискурсивного слова перший у лінгво- і соиіокультурній свідомості (на матеріалі аналізу поетичного мовлення), [в:] Незгасимий словосвіт, Харків 2011, с. 539-547. 
ми прикметника перший, що їх активно використовують поети, зокрема перший як складник прецедентного виразу перші кроки у поетичному тексті та ін., порівн.: ... був час географічних відкриттів, / і день стелився, ніби самобранно, / коли благословлялося на світ / мені, малому, / коли найперші кроки / проходячи, двоївся і троївсь, / сто сонџь роїлось, / як джмелів лапатих, / i терлись зорі / крем'яхом сухим (В. Стус, „Потоки”); Весна така - аж набувало! - добра: / Яріє рунь. Димує оболонь, - / а в пам'яті димлять на плечах роби / найперших з перших, / що пішли в огонь (Б. Олійник, „Дорога на Чорнобиль”) ${ }^{30}$.

Ненормативні форми ступенів порівняння із нагромадженням афіксів зумовлені, як видається, не лише прагненням автора до утворення певного стилістичного ефекту в поетичному або рекламному тексті, причина активного творення інновацій полягає в тому, що такі форми дають змогу передати більший обсяг інформації, підібрати влучне слово для оцінки певного предмета або явища. Як демонструють форми прикметників, утворені за допомогою префікса най- із пропуском середньої ланки ступенювання, на сучасному етапі розвитку мови із метою досягнення конкретних прагматичних цілей змінюються формальні показники традиційних, закріплених системою мови для того чи того морфологічного класу грамем, що спричиняє появу нових випадкових граматичних модифікацій, актуалізацію потенційних аксіологічних сем, виникнення різновекторних смислових асоціацій. Численність подібних порушень мовної норми засвідчує виникнення певної нової закономірності, тенденції до спрощення мови. Кваліфікація таких явищ як суто негативних або позитивних для розвитку української мови не видається можливою, оскільки розвиток мови здійснюється саме за допомогою різного роду інновацій та варіантів, що найкраще забезпечують процес комунікації.

Репрезентоване дослідження не вичерпує всього кола питань, пов'язаних iз використанням граматичних категорій прикметників як засобу виникнення прагматичної інформації. Недослідженими залишаються питання щодо використання інших префіксів-модифікаторів (зокрема префікса пре-) для створення граматичного значення оцінки, що викликає необхідність подальших досліджень виокремленої проблеми.

${ }^{30}$ Там само. 